\title{
The Pharmacological Treatment of Chronic Obstructive Pulmonary Disease
}

\author{
Adrian Gillissen, Peter Haidl, Martin Kohlhäufl, Klaus Kroegel, Thomas Voshaar, Christian Gessner
}

\section{SUMMARY}

Background: Inhaled corticosteroids (ICS) are markedly less effective against chronic obstructive pulmonary disease (COPD) than against asthma, and also have worse side effects. Whether ICS should be used to treat COPD is currently a matter of debate.

Methods: This review is based on pertinent articles retrieved by a selective search in PubMed and the Excerpta Medica Database (EMBASE) carried out in May 2015. We analyzed clinical trials of ICS for the treatment of COPD with a duration of at least one year, along with meta-analyses and COPD guidelines.

Results: ICS lower the frequency and severity of COPD exacerbations in comparison to monotherapy with a long-acting $B_{2}$-agonist, but have no effect on mortality. Compared to placebo, ICS monotherapy lessens the decline of forced expiratory volume in one second $\left(\mathrm{FEV}_{1}\right)$ over one year by merely $5.80 \mathrm{~mL}$ (statistically insignificant; 95\% confidence interval: [ $-0.28 ; 11.88]$ ) and only marginally improve quality of life. ICS use in patients with COPD increases the risk of pneumonia. A combination of ICS with a long-acting bronchodilator improves $\mathrm{FEV}_{1}$ by $133 \mathrm{~mL}[105 ; 161]$ and lowers the frequency of severe exacerbations by $39 \%$. The frequency of exacerbations is lowered mainly in patients who have many exacerbations; thus, ICS treatment is suitable only for patients with grade III or IV COPD.

Conclusion: ICS monotherapy has no clinically useful effect on pulmonary function in COPD. The main form of drug treatment for COPD is with bronchodilators, either alone or in combination with ICS. ICS can be given to patients with grade III or IV COPD to make exacerbations less frequent. Patients with an asthma-COPD overlap syndrome (ACOS) can benefit from ICS treatment.

\section{Cite this as:}

Gillissen A, Haidl P, Kohlhäufl M, Kroegel K, Voshaar T, Gessner C: The pharmacological treatment of chronic obstructive pulmonary disease. Dtsch Arztebl Int 2016; 113: 311-6. D0I: 10.3238/arztebl.2016.0311
Department of Pulmonary Medicine, Kassel General Hospital: Prof. Dr. med. Gillissen M.Sc. Fachkrankenhaus Kloster Grafschaft, Schmallenberg: Dr. med. Haidl

Klinik Schillerhöhe, Stuttgart: Prof. Dr. med. Kohlhäufl

Department of Internal Medicine I: Pneumology \& Allergology/Immunology, Friedrich Schiller University Jena: Prof. Dr. med. Dr. rer. nat. Kroegel

Department of Pneumology and Allergy, Medical Clinic III, Bethanien Hospital Moers: Dr. med. Voshaar Department of Pneumology, University of Leipzig: PD Dr. med. Gessner nhaled corticosteroids (ICS) are less clinically effective in chronic obstructive pulmonary disease (COPD) than in asthma. In asthma, they inhibit the underlying bronchial inflammation, thus optimizing both lung function and the prognosis. In COPD, the improvement they bring in terms of forced expiratory volume $\left(\mathrm{FEV}_{1}\right)$, quality of life, and prognosis is much lower. Then there is the additional dilemma that, although ICS reduce exacerbation frequency in COPD, they do not influence mortality. For this reason, the decision to use ICS in patients with COPD must be much more cautious and more carefully targeted, requiring very precise patient characterization, because their long-term use is associated with more unwanted effects than in asthma. The following drugs are licensed for treatment of COPD: beclomethasone dipropionate, budesonide, and fluticasone propionate/fluticasone furoate. In COPD_-again in contrast to asthma-ICS are used only in combination with at least one longacting bronchodilator, usually a long-acting $\beta_{2}$-agonist (LABA) (1). Unfortunately, in practice ICS are prescribed too often in COPD: $38.9 \%$ of all COPD patients ( $n=334$ out of a total of $n=859$ ) with stage I-II disease in a London cohort received ICS as monotherapy or in combination therapy, against guideline recommendations (2). For the present review, PubMed and the Excerpta Medica Database (EMBASE) were selectively searched for randomized, controlled longterm studies evaluating the effect of ICS given to COPD patients for $\geq 1$ year, alone or in combination. In addition, meta-analyses including Cochrane Reviews on particular topics were selectively included, as were review articles, 6-month studies, COPD guideline recommendations (Global Initiative for COPD [GOLD], and the recommendations of the German Respiratory Society/German Airway League (Deutsche Gesellschaft für Pneumologie und Beatmungsmedizin/Deutsche Atemwegsliga). We provide an up-to-date overview of the efficacy of ICS and their limitations, and present a recommendation for their rational use in the treatment of COPD.

\section{Features of the various therapeutic options Monotherapy with inhaled corticosteroids}

Large 6-month to 3-year studies of ICS as monotherapy in the 1990s produced variable results regarding the clinical efficacy of ICS (eTable). 
TABLE

Characteristics of asthma and chronic obstructive pulmonary disease*

\begin{tabular}{|c|c|c|}
\hline Characteristic & Probably asthma & Probably COPD \\
\hline Patient age & Disease onset $<20$ years & Disease onset $>40$ years \\
\hline Symptoms & $\begin{array}{l}\text { Symptoms are very } \\
\text { variable, occur at night or } \\
\text { in the early morning, are } \\
\text { worse on exertion or on } \\
\text { exposure to specific and } \\
\text { nonspecific triggers, and } \\
\text { respond well to asthma } \\
\text { medication }\end{array}$ & $\begin{array}{l}\text { Symptoms persist without } \\
\text { much variation; patient has } \\
\text { good days and bad days, } \\
\text { but always has symptoms, } \\
\text { chronic productive cough, } \\
\text { and dyspnea without an } \\
\text { obvious trigger }\end{array}$ \\
\hline Pulmonary function & $\begin{array}{l}\text { Airway obstruction } \\
\text { variable, responds well to } \\
\text { asthma medication }\end{array}$ & $\begin{array}{l}\text { Persistent airway } \\
\text { obstruction }\end{array}$ \\
\hline $\begin{array}{l}\text { Pulmonary function } \\
\text { between symptoms }\end{array}$ & Normal & $\begin{array}{l}\text { Persistent airway obstruc- } \\
\text { tion and hyperinflation }\end{array}$ \\
\hline Medical history & $\begin{array}{l}\text { Personal or family history } \\
\text { of asthma or allergies }\end{array}$ & $\begin{array}{l}\text { Previous diagnosis of } \\
\text { COPD or emphysema, } \\
\text { long-term (years) inhala- } \\
\text { tion exposure, usually to } \\
\text { cigarette smoke }\end{array}$ \\
\hline Chest X-ray & Normal & $\begin{array}{l}\text { Signs of pulmonary } \\
\text { hyperinflation }\end{array}$ \\
\hline
\end{tabular}

*Adapted from GOLD (1)

COPD, chronic obstructive pulmonary disease; GOLD, Global Initiative for Chronic Obstructive Lung Disease

\section{Combination of inhaled corticosteroids with long-acting} B -agonists

The eTable gives an overview of the most important ICS/LABA COPD studies that lasted for longer than 12 months and their results and limitations (eTable). TRISTAN was the first large study, investigating the effect of combined salmeterol $(2 \times 50 \mu \mathrm{g} /$ day $)$ and fluticasone $(2 \times 500 \mu \mathrm{g} /$ day $)$ in almost 1500 patients. In this study, at the end of 1 year $\mathrm{FEV}_{1}$ had improved by 133 $\mathrm{mL}[105 ; 161](\mathrm{p}<0.0001)$ in comparison to placebo, by $73 \mathrm{~mL}[46 ; 101](\mathrm{p}<0.001)$ in comparison to salmeterol, and by $95 \mathrm{~mL}[67 ; 122]$ in comparison to fluticasone $(\mathrm{p}<0.0001)$. Severe exacerbations, treated with steroids, were reduced by $39 \%$ in the combination group ( $\mathrm{p}<0.0001), 29 \%$ ( $\mathrm{p}=0.0003$ ) in the salmeterol group, and $34 \%(p=0.0001)$ in the fluticasone group. Health status (SGRQ) and symptom scores were also positively affected (8).

In the TORCH study, the fluticasone/salmeterol combination reduced the annual exacerbation frequency compared to placebo, from 1.13 to 0.85 exacerbations/year ( $\mathrm{p}<0.001$ ), but not compared to salmeterol monotherapy. This observation was exclusively a result of the salmeterol treatment, without any relevant additive effect from the ICS component. Mortality (primary outcome parameter) remained unaffected by the fluticasone/salmeterol combination (7). This is why the result of a similar study by Mahler et al. surprised no one, showing that fluticasone/salmeterol compared to placebo had no effect on time to first exacerbation (9).

Similar results came out of the long-term budesonide/formoterol studies. The combination of budesonide with formoterol reduced severe exacerbations by $23 \%[0.8 ; 40.1)$ compared to formoterol alone, by $11 \%$ [-15.9; 31.8] compared to budesonide alone, and by $24 \%$ [ $1.9 ; 41.4]$ compared to placebo. This study too included patients who responded particularly well to ICS. Accordingly, the pulmonary function values were better in the fixed combination arm than in either of the single-component arms (10). Comparison of combined meclometasone/formoterol versus formoterol alone produced a similar result (11). Combined fluticasone fuorate/vilanterol increased the time to next exacerbation in comparison to the single component arms, but the frequency of severe exacerbations did not change.

Compared to monotherapy with a long-acting $\beta_{2}$-agonist, additional administration of ICS resulted in a downward trend in the frequency of severe exacerbations, but not a significant reduction. However, the frequency of moderately severe exacerbations was reduced to $0.82 /$ year [0.72; 0.92]. This allowed calculation of a number needed to treat (NNT) of 31 [20; 93] in order to prevent one exacerbation (12). Quality of life improved slightly $(-1.88 ; 9 \%[-2.44 ;-1.33])$, although without reaching the clinically relevant threshold of -4 points (13).

It may be concluded that, compared with the single components and with placebo, despite some differences in the study comparisons, and depending on the various components used, the ICS/LABA combination mainly 


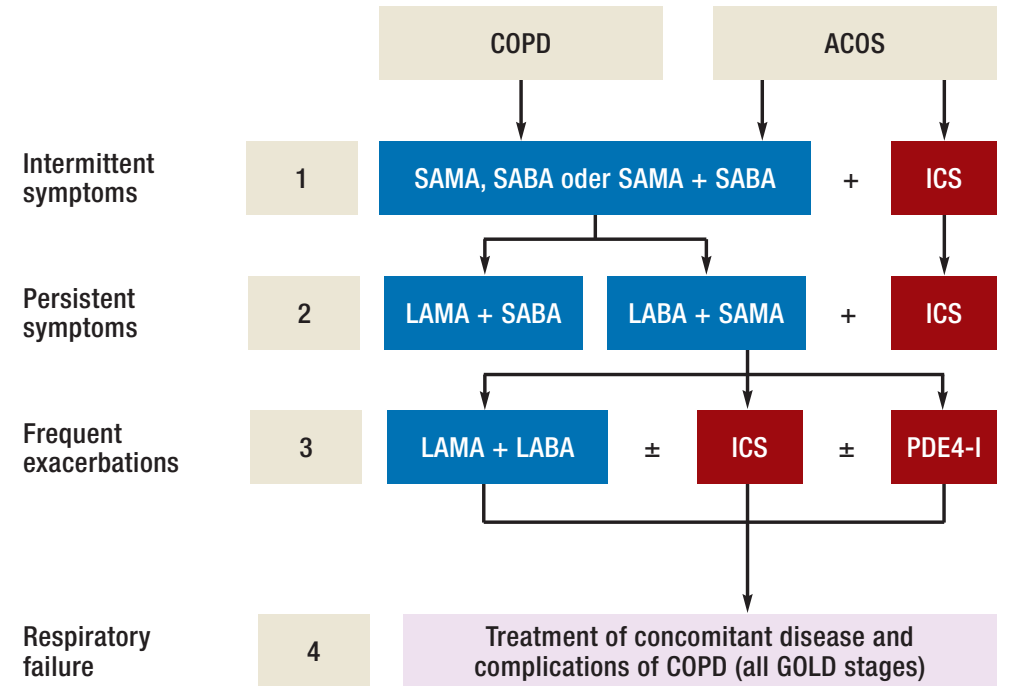

Avoidance of exposure

(e.g., smoking cessation)

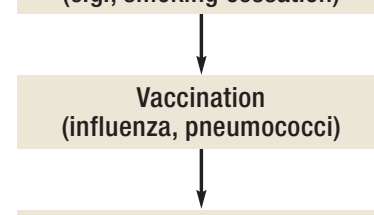

Pulmonary rehabilitation

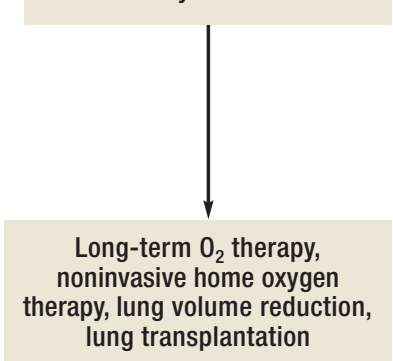

Pharmacological and nonpharmacological management of COPD

ACOS, asthma-COPD overlap syndrome; COPD, chronic obstructive pulmonary disease; ICS, inhaled corticosteroids; GOLD, Global Initiative for Chronic Obstructive Lung Disease; LAMA, long-acting anticholinergic; LABA, long-acting $B_{2}$-agonist; PDE4-I, phosphodiesterase-4 inhibitor; SAMA, short-acting muscarinic receptor antagonist; SABA, short-acting $B_{2}$-agonist

reduced exacerbation frequency in patients with frequent exacerbations. This would suggest that ICS are only suitable for patients with grade III and IV COPD who have a higher frequency of exacerbations.

\section{Combination of inhaled corticosteroid with long-acting} $B_{\text {- }}$-agonists and anticholinergics

The value of triple therapy with a combination of ICS, LABA, and a long-acting anticholinergic (LAMA, long-acting muscarinic receptor antagonist)—an important question for clinical practice-was investigated in a meta-analysis of seven studies by Kwak et al. (14). This showed that triple therapy is clinically more effective than monotherapy with tiotropium: $\mathrm{FEV}_{1}$ improved, by $63.68 \mathrm{~mL}$ [45.29; 82.73], and so did quality of life (SGRQ), by -3.11 points $[-6.0 ;-8.0]$. In a 12-week study, Welte et al. showed that triple therapy consisting of tiotropium plus budesonide/formoterol in patients with severe COPD ( $\mathrm{FEV}_{1} 38 \%$ of normal) compared with tiotropium plus placebo raised predose $\mathrm{FEV}_{1}$ by $6 \%$ and postdose $\mathrm{FEV}_{1}$ by $11 \%$. In addition, the number of severe exacerbations dropped by $62 \%$. However, in regard to this last, the study was too short and had too few patients $(n=660)$ for this to have statistical significance for clinical practice (15).
The SUMMIT study, which ended in June 2015 and was reported on in an oral presentation at the annual conference of the European Respiratory Society 2015 in Amsterdam and via a press release (www.gsk.com/ en-gb/media/press-releases/2015/gsk-and-theravanceannounce-results-from-the-summit-copd-cv-survivalstudy), investigated whether the combination of fluticasone furoate $(100 \mu \mathrm{g})$ and vilanterol $(25 \mu \mathrm{g})$, compared to the individual components or placebo, reduced all-cause mortality in 16000 COPD patients with increased cardiovascular risk after a treatment duration of 15-44 months. Mortality in the combination group was $12.2 \%$ lower than in the placebo group ( $p=0.317$ ). Annual $\mathrm{FEV}_{1}$ decline in the combination group was reduced by $8 \mathrm{~mL}(\mathrm{p}=0.019)$.

In a case-control study based on a US veterans database, triple therapy with an ICS and an inhaled LABA together with tiotropium, compared to ICS/LABA, reduced mortality (hazard ratio [HR]: 0.60 [0.45; 0.79]). At the same time, this treatment reduced both the exacerbation risk (HR: 0.84 [0.73; 0.97]) and the risk of COPD-related hospitalization (HR: 0.78 [0.62; 0.98]) (16).

To conclude, the effects on lung function and exacerbation reduction when ICS are added to existing 
LABA/LAMA therapy are small, and are clinically relevant only in the subpopulation of COPD patients at high risk of exacerbations.

\section{Combination of inhaled corticosteroids with roflumilast}

In the REACT study, giving roflumilast in addition to LABA/ICS combination therapy reduced exacerbation frequency $(0.823$ year with roflumilast versus 0.995 with placebo; $\mathrm{p}=0.0424$ ); about two-thirds of all study patients were also treated with tiotropium (triple therapy). Thus, dual anti-inflammatory treatment of this kind is clinically more effective in the patient subtype with frequent exacerbations ( $\geq 2$ /year) and symptoms of chronic bronchitis than is LABA/ICS therapy alone (17). However, unwanted gastrointestinal effects are frequent with roflumilast.

\section{Inhaled corticosteroids in COPD with eosinophil-dominated inflammation}

In a disease otherwise dominated by neutrophils, sputum eosinophil percentages are above $2 \%$ or higher in about $10 \%$ to $40 \%$ (18) or even up to $60 \%$ of all patients with frequent exacerbations (19). Blood eosinophil counts of $\geq 340$ cells $/ \mu \mathrm{L}$ are associated with a 1.76 times higher exacerbation rate (20). In patients with a blood eosinophil percentage of $\geq 2 \%$ (or 200 cells/ $\mu \mathrm{L}$ or higher), vilanterol/fluticasone furoate in comparison with vilanterol reduced the annual exacerbation frequency by $29 \%$ ( 0.79 versus 0.89 ; $\mathrm{p}<0.0001$ ). If the eosinophil percentage was $\geq 2 \%$ to $<4 \%$, the reduction was $32 \%$; if the eosinophil percentage was $\geq 4 \%$ up to $<6 \%$, the reduction was $42 \%$ (19).

\section{Inhaled corticosteroids in mixed-type asthma and COPD}

The asthma-COPD mixed-type is currently subsumed under the term ACOS (asthma-COPD overlap syndrome) (21). Between $5 \%$ and $20 \%$ of all patients with COPD also show features of asthma. If the overlap is characterized by sputum and/or blood eosinophilia, ICS improve $\mathrm{FEV}_{1}$ significantly more than in patients in whom this type of inflammation is not dominant (19, 22). A single-center study carried out on ACOS patients in Korea did not find an ICS-related drop in exacerbation frequency, improvement of lung function, or quality of life (23). The small study size and lack of patient selection according to dominant phenotype could explain this finding. The absence of a definition of ACOS, the small number of studies carried out on this topic, and the comparative heterogeneity of the original studies make it hard to draw conclusions for clinical practice, and therefore we will not enter into this discussion here. Finally, all that remains is the recommendation to treat the primarily dominant disease in the mixed type.

To conclude, giving roflumilast to unstable COPD patients who have already received maximum inhalation treatment (ICS/LABA/tiotropium) reduces exacerbation frequency more than treatment with ICS/ LABA alone. ICS treatment improves lung function more in patients with features of asthma (Table) than in those with COPD. ICS reduce exacerbation frequency in dependence on blood eosinophil count.

\section{Side effects and differences in efficacy of various ICS}

A Canadian cohort study found that ICS increased the risk of pneumonia in COPD patients to $69 \%$ in a doserelated and duration-related manner (relative risk [RR]: 1.69 [1.63; 1.75]). The risk was higher with fluticasone treatment (RR: 2.10 [1.93; 2.10]) than with budesonide (RR: 1.17 [1.09; 1.26]), thus confirming the results of prospective studies of ICS in COPD (24). Depending on the ICS product in use, the ICS dose, and the duration of the study, but not the drug combined with ICS, a number needed to harm (NNH) of 14 to 20 was calculated for a treatment duration of 24 weeks or more (25). Despite the risk of pneumonia, exacerbation frequency fell in the prospective studies, because the pneumonia cases seen were predominantly low-grade, so this risk should not be important in practice.

\section{Cessation of ICS treatment}

After abrupt cessation of 4 months' treatment with inhaled fluticasone $(2 \times 500 \mu \mathrm{g} / \mathrm{day})$, the exacerbation risk at the end of the 6-month study period in the placebo group was increased by a factor of 1.5 [1.05; 2.1] compared to the group that received fluticasone (26). The findings for symptom score and quality of life reflected this. Withdrawal of fluticasone $(2 \times 500 \mu \mathrm{g} /$ day $)$ compared to continuation of the initial fluticasone/salmeterol combination therapy resulted after 1 year in an increase in the annual decline in $\mathrm{FEV}_{1}$ to $-4.4 \%$ versus $-0.1 \%$. In addition, the frequency of severe exacerbations increased (1.6 versus 1.3/year) (27). In the WISDOM study, however, it was demonstrated that in stable but severely ill COPD patients $\left(\mathrm{FEV}_{1} 34 \%\right.$ of normal), gradual reduction of ICS over a 9-month observation period, during which the patients were treated only with inhaled bronchodilators, did not increase the exacerbation risk. However, lung function deteriorated significantly ( $40 \mathrm{~mL}$ ) compared to the ICS group (28).

To conclude, ICS treatment slightly raises the incidence of pneumonia, but apparently only mild forms of pneumonia are involved. ICS can be gradually reduced in stable COPD patients without increasing the frequency of exacerbations.

\section{Suggestions for the use of ICS in clinical practice}

Unlike in asthma, in COPD ICS are in every respect inferior to long-term, long-acting bronchodilators for symptom control. The primary indication for their use is in patients who suffer frequent exacerbations. Regarding the correct use of ICS in COPD, we make the following recommendations (Figure):

- Only use ICS in combination with at least one inhaled bronchodilator.

- The primary indication for ICS is to reduce a higher exacerbation frequency in patients with grade III or IV COPD (COPD groups C and D) 


\section{KEY MESSAGES}

- Inhaled corticosteroids (ICS) are much less effective in chronic obstructive pulmonary disease (COPD) than they are in asthma.

- The effect of ICS on reducing the annual decline in $\mathrm{FEV}_{1}$ is clinically insignificant.

- ICS reduce the frequency of COPD exacerbations; their efficacy increases as blood eosinophil counts rise.

- ICS are used as a second-line treatment after bronchodilators.

- In stable patients, ICS can be gradually reduced.

with a $\mathrm{FEV}_{1}<50 \%$ of normal and/or who have two or more exacerbations per year. Stage I and II COPD (groups A and B) should be treated in the first instance with one or two inhaled bronchodilators, in accordance with the German National Disease Management Guideline COPD (NVLCOPD) and the GOLD guideline (1).

- Because of the risk of pneumonia, patients with an increased incidence of pneumonia should be given ICS at the lowest possible dosage (29).

- In COPD patients with features of asthma (Table) and a raised blood eosinophil count (e.g., $\geq 2 \%$ ), ICS treatment should be considered as a therapeutic option early on.

- Gradual reduction of ICS can be justified in stable patients (28).

- ICS should not be used with the aim of improving lung function.

It is essential to ensure that the prescribed inhalation systems are correctly used. Patients should be given repeated training in how to carry out their inhalation treatment properly.

\section{Conflict of interest statement}

Professor Gillissen has received consultancy fees from Chiesi, Teva, Elpen, and Berlin-Chemie. He has had conference fees reimbursed by Chiesi and Teva. He has had travel expenses reimbursed by Chiesi, Teva, Boehringer Ingelheim,

Elpen, Almirall, and Berlin-Chemie. He has received lecture fees from AstraZeneca, Elpen, Chiesi, Boehringer Ingelheim, and Berlin-Chemie.

Dr. Haidl has received consultancy fees from Chiesi and Mundipharma. He has received lecture fees from GlaxoSmithKline (GSK), Chiesi, Mundipharma, AstraZeneca, Novartis, and Boehringer Ingelheim.

Professor Kroegel has received consultancy fees from Chiesi.

Dr. Voshaar has received consultancy fees from Chiesi, Boehringer Ingelheim, Novartis, Teva, and Berlin-Chemie. He has received lecture fees from Chiesi, Boehringer Ingelheim, Teva, and Berlin-Chemie.

Dr. Gessner has received consultancy fees from Novartis, Chiesi, Teva, Boehringer Ingelheim, and AstraZeneca. He has received lecture fees from Chiesi, Teva, Novartis, Boehringer Ingelheim, and AstraZeneca. He has received third-party research funding from Chiesi, Novartis, Boehringer Ingelheim, Teva, AstraZeneca, and GSK.

Professor Kohlhäufl declares that no conflict of interest exists.

Manuscript received on 29 July 2015, revised version accepted on 1 February 2016.

Translated from the original German by Kersti Wagstaff, MA.

\section{REFERENCES}

1. Committee GE: Global initiative for chronic obstructive lung disease. www.goldcopd.com 2015 (last accessed on 20 December 2015).

2. White P, Thornton H, Pinnock H, Georgopoulou S, Booth HP: Overtreatment of COPD with inhaled corticosteroids -implications for safety and costs: cross-sectional observational study. PLoS One 2013; 8: e75221.

3. Vestbo J, Sørensen T, Lange P, Brix A, Torre P, Viskum K: Long-term effect of inhaled budesonide in mild and moderate chronic obstructive pulmonary disease: a randomised controlled trial. Lancet 1999; 355: 1819-23.

4. Pauwels RA, Lofdahl CG, Laitinen LA, et al.: Long-term treatment with inhaled budesonide in persons with mild chronic obstructive pulmonary disease who continue smoking. N Engl J Med 1999; 340: 1948-53

5. Burge PS, Calverley PMA, Jones PW, Spencer S, Anderson J: Randomised, placebo-controlled study of fluticasone propionate in patients with moderate to severe chronic obstructive pulmonary disease: the ISOLDE trial. BMJ 2000; 320: 1297-303.

6. Group TLHS: Effect of inhaled triamcinolone on the decline in pulmonary function in chronic obstructive pulmonary disease. N Engl J Med 2000; 343: 1902-9.

7. Calverley PMA, Anderson JA, Celli BR, et al.: Salmeterol and fluticasone propionate and survival in chronic obstructive pulmonary disease. N Engl J Med 2007; 356: 775-89.

8. Calverley PMA, Pauwels RA, Vestbo J, et al.: Combined salmeterol and fluticasone in the treatment of chronic obstructive pulmonary disease: a randomised controlled trial. Lancet 2003; 361: 449-56.

9. Mahler DA, Wire P, Horstman D, et al.: Effectiveness of fluticasone propionate and salmeterol combination delivered via the diskus device in the treatment of chronic obstructive pulmonary disease. Am J Respir Crit Care Med 2002; 166: 1084-91.

10. Szafranski W, Ramirez A, Peterson S: Budesonide/Formoterol in a single inhaler provides sustained improvements in lung function in patients with moderate to severe COPD. Eur Respir J 2002; 20: 397s

11. Calverley PM, Kuna P, Monso E, et al.: Beclomethasone/formoterol in the management of COPD: a randomised controlled trial. Respir Med 2010; 104: 1858-68.

12. Sobieraj DM, White CM, Coleman Cl: Benefits and risks of adjunctive inhaled corticosteroids in chronic obstructive pulmonary disease: a meta-analysis. Clin Ther 2008; 30: 1416-25.

13. Rodrigo GJ, Nannini LJ, Rodriguez-Roisin R: Safety of long-acting beta-agonists in stable COPD: a systematic review. Chest 2008; 133: 1079-87.

14. Kwak MS, Kim E, Jang EJ, Kim HJ, Lee CH: The efficacy and safety of triple inhaled treatment in patients with chronic obstructive pulmonary disease: a systematic review and meta-analysis using Bayesian methods. Int J Chron Obstruct Pulmon Dis 2015; 10 : 2365-76.

15. Welte T, Miravitlles M, Hernandez P, et al.: Efficacy and tolerability of budesonide/formoterol added to tiotropium in patients with chronic obstructive pulmonary disease. Am J Respir Crit Care Med 2009; 180: 741-50.

16. Lee TA, Wilke C, Joo M, et al.: Outcomes associated with tiotropium use in patients with chronic obstructive pulmonary disease. Arch Intern Med 2009; 169: 1403-10.

17. Martinez FJ, Calverley PM, Goehring UM, Brose M, Fabbri LM, Rabe $\mathrm{KF}$ : Effect of roflumilast on exacerbations in patients with severe chronic obstructive pulmonary disease uncontrolled by combination therapy (REACT): a multicentre randomised controlled trial. Lancet 2015; 385: 857-66.

18. Hattotuwa KL, Gizycki MJ, Ansari TW, Jeffery PK, Barnes NC: The effect of inhaled fluticasone on airway inflammation in chronic obstructive pulmonary disease: a double-blind, placebo-controlled biopsy study. Am J Respir Crit Care Med 2002; 165: 1592-6.

19. Pascoe S, Locantore N, Dransfield MT, Barnes NC, Pavord ID: Blood eosinophil counts, exacerbations, and response to the addition of inhaled fluticasone furoate to vilanterol in patients with chronic 
obstructive pulmonary disease: a secondary analysis of data from two parallel randomised controlled trials. Lancet Respir Med 2015; 3: 435-42.

20. Vedel-Krogh S, Nielsen SF, Lange P, Vestbo J, Nordestgaard BG: Blood eosinophils and exacerbations in COPD: the Copenhagen General Population Study. Am J Respir Crit Care Med 2015. (Epub ahead of print)

21. Global Initiative for Asthma (GINA): Global strategy for asthma management and prevention. www.ginasthma.org/documents/4 (last accessed on 20 December 2015).

22. Kitaguchi Y, Komatsu Y, Fujimoto K, Hanaoka M, Kubo K: Sputum eosinophilia can predict responsiveness to inhaled corticosteroid treatment in patients with overlap syndrome of COPD and asthma Int J Chron Obstruct Pulmon Dis 2012; 7: 283-9.

23. Lim HS, Choi SM, Lee J, et al.: Responsiveness to inhaled corticosteroid treatment in patients with asthma-chronic obstructive pulmonary disease overlap syndrome. Ann Allergy Asthma Immunol 2014; 113: 652-7.

24. Suissa S, Patenaude V, Lapi F, Ernst P: Inhaled corticosteroids in COPD and the risk of serious pneumonia. Thorax 2013; 68: 1029-36.

25. Eurich DT, Lee C, Marrie TJ, Majumdar SR: Inhaled corticosteroids and risk of recurrent pneumonia: a population-based, nested casecontrol study. Clin Infect Dis 2013; 57: 1138-44.

26. Valk van der P, Monninkhoff E, Palen van der J, Zielhuis G, Heerwaarden van $\mathrm{C}$ : Effect of discontinuation of inhalaed corticosteroids in patients with chronic obstructive pulmonary disease: the COPE study. Am J Respir Crit Care Med 2002; 166: 1358-63.

27. Wouters EF, Postma DS, Fokkens B, et al.: Withdrawal of fluticasone propionate from combined salmeterol/fluticasone treatment in patients with COPD cause immediate and sustained disease deterioration: a randomised controlled trial. Thorax 2005; 60: 480-7.

28. Magnussen H, Disse B, Rodriguez-Roisin R, et al.: Withdrawal of inhaled glucocorticoids and exacerbations of COPD. N Engl J Med 2014; 371: 1285-94

29. Suissa S: Number needed to treat in COPD: exacerbations versus pneumonias. Thorax 2013; 68: 540-3.

30. Calverley PM, Rennard S, Nelson HS, et al.: One-year treatment with mometasone furoate in chronic obstructive pulmonary disease. Respir Res 2008; 9: 73

31. Anzueto A, Ferguson GT, Feldman G, et al.: Effect of fluticasone propionate/salmeterol (250/50) on COPD exacerbations and impact on patient outcomes. COPD 2009; 6: 320-9.

32. Szafranski W, Ramirez A, Menga G, et al.: Efficacy and safety of budesonide/formoterol in the management of chronic obstructive pulmonary disease. Eur Respir J 2003; 21: 74-81.
33. Lapperre TS, Snoeck-Stroband JB, Gosman MM, et al.: Effect of fluticasone with and without salmeterol on pulmonary outcomes in chronic obstructive pulmonary disease: a randomized trial. Ann Intern Med 2009; 151: 517-27.

34. Calverley PMA, Boonsawat W, Cseke Z, Zhong N, Peterson S, Olsson $\mathrm{H}$ : Maintenance therapy with budesonide and formoterol in chronic obstructive pulmonary disease. Eur Respir J 2003; 22: 912-9.

35. Calverley PMA, Olsson $\mathrm{H}$ : Budesonide/formoterol in a single inhale sustains improvements in lung function over 12 months compared with monocomponents and placebo in patients with COPD. Am J Respir Crit Care Med 2003; 167: A319.

36. Rennard SI, Tashkin DP, McElhattan J, et al.: Efficacy and tolerability of budesonide/formoterol in one hydrofluoroalkane pressurized metered-dose inhaler in patients with chronic obstructive pulmonary disease: results from a 1-year randomized controlled clinical trial. Drugs 2009; 69: 549-65.

37. Crim C, Calverley PMA, Anderson JA, et al.: Pneumonia risk in COPD patients receiving inhaled corticosteroids alone or in combination: TORCH study results. Eur Respir J 2009; 34: 641-7.

38. Ferguson GT, Anzueto A, Fei R, Emmett A, Knobil K, Kalberg C: Effect of fluticasone propionate/salmeterol (250/50 microg) or salmeterol (50 microg) on COPD exacerbations. Respir Med 2008; 102: 1099-108.

39. Wedzicha JA, Calverley PMA, Seemungal TAR, Hagan G, Ansan Z, Stockley RA: The prevention of COPD exacerbations by salmeterol/ fluticasone propionate or tiotropium bromide. Am J Respir Crit Care Med 2008; 177: 19-26.

40. Aaron SD, Vandernheen KL, Fergusson D, et al.: Tiotropium in combination with placebo, salmeterol, or fluticasone-salmeterol for treatment of chronic obstructive pulmonary disease. Ann Intern Med 2007; 146: 545-55

\section{Corresponding author:}

Prof. Dr. Adrian Gillissen

Klinikum Kassel

Klinik für Lungen- und Bronchialmedizin

Mönchebergstr. 41-43

34125 Kassel, germany

adrian.gillissen@web.de

(2)

Supplementary material

For eReferences please refer to: www.aerzteblatt-international.de/ref1816

eTable:

www.aerzteblatt-international.de/16m0311 


\section{Supplementary material to:}

\section{The Pharmacological Treatment of Chronic Obstructive Pulmonary Disease}

by Adrian Gillissen, Peter Haidl, Martin Kohlhäufl, Klaus Kroegel, Thomas Voshaar, and Christian Gessner

Dtsch Arztebl Int 2016; 113: 311-6. D0l: 10.3238/arztebl.2016.0311

\section{EREFERENCES}

e1. Yang IA, Fong KM, Sim EH, Black PN, Lasserson TJ: Inhaled corticosteroids for stable chronic obstructive pulmonary disease.

Cochrane Database Syst Rev 2007; (2): CD002991

\section{eTABLE}

Important placebo-controlled, double-blind, multicenter studies*

\begin{tabular}{|c|c|c|c|c|}
\hline Study & $\begin{array}{l}\text { Comparison groups and number } \\
\text { of participants }\end{array}$ & Main patient inclusion criteria & $\begin{array}{l}\text { Study effects and significant } \\
\text { unwanted effects }\end{array}$ & $\begin{array}{l}\text { Study } \\
\text { duration }\end{array}$ \\
\hline \multicolumn{5}{|l|}{ ICS monotherapy studies } \\
\hline Vestbo 1999 (3) & $\begin{array}{l}\text { - Bud } 800 \mu \mathrm{g} \text { plus } 400 \mu \mathrm{g} \text { daily } \\
\text { for } 6 \text { months } \\
\text { then } 2 \times 400 \mu \mathrm{g}(\mathrm{n}=145) \\
\text { - Placebo }(\mathrm{n}=145)\end{array}$ & $\mathrm{FEV}_{1} /$ vital capacity $\leq 0.7$ & $\begin{array}{l}\mathrm{FEV}_{1} \text { decline/year (primary outcome } \\
\text { parameter): } 41.8 \mathrm{~mL} \text { (placebo) and } \\
45.1 \mathrm{~mL} \text { (Bud); } 155 \text { exacerbations } \\
\text { in the Bud group and } 161 \text { in placebo } \\
\text { group; no significant differences } \\
\text { between groups }\end{array}$ & 3 years \\
\hline Pauwels 1999 (4) & $\begin{array}{l}\text { - Bud } 2 \times 400 \mu g(n=634) \\
\text { - Placebo }(n=643)\end{array}$ & $\begin{array}{l}\geq 10 \text { pack-years } \\
\text { FEV }_{1} \geq 50 \% \text { of normal }\end{array}$ & $\begin{array}{l}\mathrm{FEV}_{1} \text { decline at end of study (prima- } \\
\text { ry outcome parameter): } 140 \mathrm{~mL} \\
\text { (Bud) vs. } 180 \mathrm{~mL} \text { (placebo); the dif- } \\
\text { ference was primarily in the first } 6 \\
\text { months, during which FEV } \mathrm{V}_{1} \text { rose in } \\
\text { the Bud group but declined in the } \\
\text { placebo group. } 10 \% \text { (Bud) vs. } 4 \% \\
\text { (placebo) of patients suffered skin } \\
\text { injuries. }\end{array}$ & 3 years \\
\hline Calverley 2008 (30) & $\begin{array}{l}\text { - Mometasone } 2 \times 400 \mu \mathrm{g}(\mathrm{n}=308) \\
\text { - Mometasone } 1 \times 800 \mu \mathrm{g}(\mathrm{n}=308) \\
\text { - Placebo }(\mathrm{n}=295)\end{array}$ & $\begin{array}{l}\geq 10 \text { pack-years } \\
\text { FEV } 130-70 \% \text { of normal }\end{array}$ & $\begin{array}{l}\mathrm{FEV}_{1} \text { change compared to start of } \\
\text { study (primary study endpoint): } 50 \\
\mathrm{~mL} \text { (mometasone } 1 \times 800 \mu \mathrm{g}) \mathrm{vs} \text {. } \\
53 \mathrm{~mL}(2 \times 400 \mu \mathrm{g}) \mathrm{vs} .-19 \mathrm{~mL} \\
\text { (placebo); lower exacerbation } \\
\text { frequency ( } \mathrm{p}=0.031) \text {, health status } \\
\text { and quality of life in both mometa- } \\
\text { sone groups vs. placebo }\end{array}$ & 1 year \\
\hline Burge 2000 ISOLDE (5) & $\begin{array}{l}\text { - FP } 2 \times 500 \mu g(n=376) \\
\text { - Placebo }(n=375)\end{array}$ & $\begin{array}{l}\mathrm{FEV}_{1} \geq 800 \mathrm{~mL} \text {, but }<85 \% \text { of } \\
\text { normal }\end{array}$ & $\begin{array}{l}\text { No differences between groups in } \\
\text { annual } F E V_{1} \text { decline (primary out- } \\
\text { come parameter); annual exacerba- } \\
\text { tion frequency: } 1.32 \text { (FP) vs. } 0.99 \\
\text { (placebo; } p=0.026 \text { ); health status } \\
\text { deteriorated by } 2.0 \text { (FP) vs. } 3.2 \\
\text { points (placebo; } p=0.0043 \text { ) }\end{array}$ & 3 years \\
\hline \multicolumn{5}{|l|}{ ICS/LABA studies } \\
\hline Anzueto 2009 (31) & $\begin{array}{l}\text { - Salm } 2 \times 50 \mu \mathrm{g}(\mathrm{n}=403) \\
\text { - Salm/FP } 2 \text { × 50/250 } \mu \mathrm{g}(\mathrm{n}=394)\end{array}$ & $\begin{array}{l}\geq 10 \text { pack-years } \\
\mathrm{FEV}_{1} \leq 50 \% \text { of normal } \\
\geq 1 \text { severe exacerbation within the } \\
12 \text { months before study enrollment }\end{array}$ & $\begin{array}{l}\text { Exacerbation frequency (primary } \\
\text { outcome parameter) reduced with } \\
\text { Salm/FP compared to Salm by } \\
30.4 \%(1.10 \text { vs. } 1.59 \text { exacerbations/ } \\
\text { year; } p<0.001) \text {; more cases of } \\
\text { pneumonia in Salm/FP group }(7 \%) \\
\text { vs. Salm group }(2 \%)\end{array}$ & 1 year \\
\hline
\end{tabular}




\begin{tabular}{|c|c|c|c|c|}
\hline Study & $\begin{array}{l}\text { Comparison groups and number } \\
\text { of participants }\end{array}$ & Main patient inclusion criteria & $\begin{array}{l}\text { Study effects and significant } \\
\text { unwanted effects }\end{array}$ & $\begin{array}{l}\text { Study } \\
\text { duration }\end{array}$ \\
\hline Calverley 2010 (11) & $\begin{array}{l}\text { - Form } 2 \times 12 \mu \mathrm{g}(\mathrm{n}=239) \\
\text { - Form/Bud } 2 \times 12 / 400 \mu \mathrm{g}(\mathrm{n}=242) \\
\text { - Form/Bec } 2 \times 12 / 200 \mu \mathrm{g}(\mathrm{n}=237)\end{array}$ & $\begin{array}{l}\geq 20 \text { pack-years } \\
\mathrm{FEV}, 50-30 \% \text { of normal } \\
\geq 1 \text { severe exacerbation within the } \\
2 \text { to } 12 \text { months before study } \\
\text { enrollment }\end{array}$ & $\begin{array}{l}\mathrm{FEV}_{1} \text { change compared to start of } \\
\text { study and exacerbation frequency } \\
\text { (combined endpoint): FEV } 1 \\
\text { improvement of } 0.077 \mathrm{~L} \text { (Form/Bec), } \\
0.080 \mathrm{~L} \text { (Form/Bud) vs. } 0.026 \mathrm{~L} \\
\text { (Form; } \mathrm{p}=0.046 \mathrm{vs} \text {. Form/Bec); } \\
\text { exacerbations/year } 0.414 \mathrm{vs} .0 .423 \\
\text { vs. } 0.431=\text { no significant differ- } \\
\text { ences between groups (including in } \\
\text { relation to quality of life, symptoms, } \\
\text { and use of emergency medication) }\end{array}$ & 11 months \\
\hline Szafranski 2003 (32) & $\begin{array}{l}\text { - Form } 2 \times 12 \mu \mathrm{g}(\mathrm{n}=201) \\
\text { - Bud } 2 \times 320 \mu \mathrm{g}(\mathrm{n}=198) \\
\text { - Form/Bud } 4 \times 4.5 / 160 \mu \mathrm{g} \\
\quad(\mathrm{n}=208) \\
\text { - Placebo }(\mathrm{n}=205)\end{array}$ & $\begin{array}{l}\geq 10 \text { pack-years } \\
\text { FEV }_{1} \leq 50 \% \text { of normal }\end{array}$ & $\begin{array}{l}\text { Reduction in severe exacerbations } \\
\text { with Form/Bud vs. placebo } 24 \% \text {, vs. } \\
\text { Form } 23 \% \text {; FEV } \text { V }_{1} \text { increase } 15 \% \text { vs. } \\
\text { placebo and } 9 \% \text { vs. Bud (both } \\
\text { primary outcome parameters) }\end{array}$ & 1 year \\
\hline Lapperre 2009 (33) & $\begin{array}{l}\text { - FP } 2 \times 500 \mu \mathrm{g}(n=26) \\
\text { - Salm/FP } 2 \times 50 / 500 \mu \mathrm{g}(\mathrm{n}=28) \\
\text { - FP followed by placebo }(n=31) \\
\text { - Placebo }(n=29)\end{array}$ & $\begin{array}{l}\geq 10 \text { pack-years } \\
\mathrm{FEV} \mathrm{V}_{1} 30-70 \% \text { of normal } \\
1 \times \mathrm{COPD} \text { exacerbation/year in the } \\
\text { previous } 3 \text { years }\end{array}$ & $\begin{array}{l}\text { Reduced inflammatory cells in } \\
\text { bronchial mucosal biopsy samples; } \\
\text { reduced bronchial hyperreactivity }\end{array}$ & 2.5 years \\
\hline $\begin{array}{l}\text { Calverley } 2003 \text { (TRISTAN) } \\
\text { (34) }\end{array}$ & $\begin{array}{l}\text { - Salm } 2 \times 50 \mu \mathrm{g}(\mathrm{n}=372) \\
\text { - FP } 2 \times 500 \mu \mathrm{g}(\mathrm{n}=374) \\
\text { - Salm/FP } 2 \times 50 / 500 \mu \mathrm{g}(\mathrm{n}=358) \\
\text { - Placebo }(\mathrm{n}=361)\end{array}$ & $\begin{array}{l}\geq 10 \text { pack-years } \\
\text { FEV } V_{1} 25-70 \% \text { of normal } \\
1 \times C O P D \text { exacerbation/year in the } \\
3 \text { preceding years }\end{array}$ & $\begin{array}{l}\mathrm{FEV}_{1} \text { improvement after } 12 \text { months } \\
\text { of treatment (primary endpoint) with } \\
\text { Salm/FP vs. placebo ( } 133 \mathrm{~mL} \text {, } \\
\text { confidence interval: [105; 161]); } \\
\text { in addition, improvement in health } \\
\text { status and symptom reduction; } \\
\text { Salm } 73 \mathrm{~mL} ; \mathrm{p}<0.0001 \text { ) and FP } 95 \\
\mathrm{~mL} \text { vs. placebo (all comparisons } \\
p<0.0001 \text { ) }\end{array}$ & 1 year \\
\hline Calverley 2003 (35) & $\begin{array}{l}\text { - Form } 2 \times 9 \mu \mathrm{g}(\mathrm{n}=255) \\
\text { - Bud } 2 \times 400 \mu \mathrm{g}(\mathrm{n}=257) \\
\text { - Form/Bud } 2 \times 9 / 320 \mu \mathrm{g}(\mathrm{n}=254) \\
\text { - Placebo }(\mathrm{n}=256)\end{array}$ & $\begin{array}{l}\geq 10 \text { pack-years } \\
\text { FEV } V_{1}<50 \% \text { of normal } \\
1 \times \text { COPD exacerbation/year } 2 \text { to } \\
12 \text { months before study enrollment }\end{array}$ & $\begin{array}{l}\text { Reduction of time to first exacerba- } \\
\text { tion (primary outcome parameter) } \\
\text { with Form/Bud vs. Bud }(22.7 \%) \text {, vs. } \\
\text { Form }(29.5 \%) \text { and vs. placebo } \\
(28.5 \%, p=0.006) ; \text { reduction in } \\
\text { exacerbation frequency with Form/ } \\
\text { Bud vs. placebo (23.6\%; } p=0.029) \\
\text { and Form (25.5\%); but not vs. Bud } \\
(13.6 \%)\end{array}$ & 1 year \\
\hline Rennard 2009 (36) & $\begin{array}{l}\text { - Form } 2 \times 9 \mu \mathrm{g}(\mathrm{n}=495) \\
\text { - Form/Bud } 2 \times 9 / 160 \mu \mathrm{g}(\mathrm{n}=494) \\
\text { - Form/Bud } 2 \times 9 / 320 \mu \mathrm{g}(\mathrm{n}=494) \\
\text { - Placebo }(\mathrm{n}=481)\end{array}$ & $\begin{array}{l}>10 \text { pack-years } \\
\text { FEV }_{1} \leq 50 \% \text { of normal }\end{array}$ & $\begin{array}{l}\text { Primary combined endpoint: trough } \\
\text { FEV } V_{1} \text { was better in the Form/Bud } \\
9 / 320 \text { group than in the placebo } \\
\text { group }(p<0.001) \text { or the Form group } \\
(p=0.023) \text {; both Form/Bud groups } \\
\text { were better vs. placebo for the } 1-h \\
\text { post-dose } F E V_{1} \text { parameter } \\
\text { ( } p<0.001) \text {; both combinations } \\
\text { extended the time to first exacerba- } \\
\text { tion and the exacerbation frequency } \\
\text { vs. placebo }(p<0.004 / p<0.001) \text { and } \\
\text { Form }(p=0.026 / p<0.004)\end{array}$ & 1 year \\
\hline Calverley (TORCH) 2007 (7) & $\begin{array}{l}\text { - Salm } 2 \times 50 \mu \mathrm{g}(\mathrm{n}=1521) \\
\text { - FP } 2 \times 500 \mu \mathrm{g}(\mathrm{n}=1534) \\
\text { - Salm/FP } 2 \times 50 / 500 \mu \mathrm{g}(\mathrm{n}=1533) \\
\text { - Placebo }(\mathrm{n}=1524)\end{array}$ & $\begin{array}{l}>10 \text { pack-years } \\
\mathrm{FEV}_{1}<60 \% \text { of normal }\end{array}$ & $\begin{array}{l}\text { No difference between groups in } \\
\text { terms of mortality (primary end- } \\
\text { point); FP/Salm reduced the exacer- } \\
\text { bation frequency from } 1.13 \text { to } \\
0.85 / y e a r \text { and improved health } \\
\text { status and FEV }(p<0.001) \text { vs. } \\
\text { placebo; more cases of pneumonia } \\
\text { in FP and Salm/FP groups vs. Salm } \\
\text { and placebo groups ( } 84 \text { and } 88 \text { vs. } \\
52 \text { and } 52 / 1000 \text { treatment-years) }\end{array}$ & 3 years \\
\hline Ferguson 2008 (38) & $\begin{array}{l}\text { - Salm } 2 \times 50 \mu \mathrm{g}(\mathrm{n}=388) \\
\text { - Salm/FP } 2 \times 50 / 250 \mu \mathrm{g}(\mathrm{n}=394)\end{array}$ & $\begin{array}{l}>10 \text { pack-years } \\
F E V_{1} \leq 50 \% \text { of normal } \\
\geq 1 \text { exacerbation within the } \\
12 \text { months before study enrollment }\end{array}$ & $\begin{array}{l}\text { Exacerbations/year (primary out- } \\
\text { come parameter): } 1.06 \text { (Salm/FP) } \\
\text { vs. } 1.53 \text { (Salm; } p<0.001) ; \text { other } \\
\text { effects of Salm/FP: time to first } \\
\text { exacerbation extended by } 25 \% \\
\text { ( } p=0.003 \text { ), severe steroid- } \\
\text { dependent exacerbations reduced } \\
\text { by } 40 \% \text { ( } p<0.001) ; \text { pneumonia inci- } \\
\text { dence: } 7 \% \text { (Salm/FP) vs. } 7 \% \text { (Salm) }\end{array}$ & 1 year \\
\hline
\end{tabular}




\begin{tabular}{|c|c|c|c|c|}
\hline Study & $\begin{array}{l}\text { Comparison groups and number } \\
\text { of participants }\end{array}$ & Main patient inclusion criteria & $\begin{array}{l}\text { Study effects and significant } \\
\text { unwanted effects }\end{array}$ & $\begin{array}{l}\text { Study } \\
\text { duration }\end{array}$ \\
\hline \multicolumn{5}{|c|}{ ICSILABA-tiotropium comparative studies } \\
\hline $\begin{array}{l}\text { Wedzicha (INSPIRE) } 2008 \\
\text { (39) }\end{array}$ & $\begin{array}{l}\text { - Tiotropium } 1 \times 18 \mu \mathrm{g}(\mathrm{n}=665) \\
\text { - Salm/FP } 2 \text { × 50/500 } \mu \mathrm{g}(\mathrm{n}=658)\end{array}$ & $\begin{array}{l}\geq 10 \text { pack-years } \\
\text { FEV }_{1} \leq 50 \% \text { of normal }\end{array}$ & $\begin{array}{l}\text { No difference between groups as to } \\
\text { use of the healthcare system } \\
\text { (primary outcome parameter: use of } \\
\text { the healthcare system); annual } \\
\text { exacerbation frequency: } 1.28 \\
\text { (Salm/FP) vs. } 1.32 \text { (tiotropium), } \\
\text { quality of life (SGRQ): } 2.1 \text { lower in } \\
\text { Salm/FP group vs. tiotropium group; } \\
\text { mortality: } 3 \% \text { (Salm/FP) vs. } 6 \% \\
\text { (tiotropium; } p=0.032) \text {; high inci- } \\
\text { dence of pneumonia in the Salm/FP } \\
\text { group ( } p=0.008) \text {. }\end{array}$ & 2 years \\
\hline Aaron 2007 (40) & $\begin{array}{l}\text { - Tiotropium } 1 \times 18 \mu \mathrm{g} \\
\text { - Tiotropium } 1 \times 18 \mu \mathrm{g} \\
\text { + Salm } 2 \times 50 \mu \mathrm{g} \\
\text { - Tiotropium } 1 \times 18 \mu \mathrm{g} \\
\text { + Salm/FP }(2 \times 50 / 500 \mu \mathrm{g})\end{array}$ & $\begin{array}{l}\geq 10 \text { pack-years } \\
\mathrm{FEV} \mathrm{V}_{1}<65 \% \text { of normal } \\
\geq 1 \text { exacerbation } 12 \text { months before } \\
\text { study enrollment }\end{array}$ & $\begin{array}{l}\text { No difference between the } 3 \text { groups } \\
\text { in terms of exacerbation frequency } \\
\text { (primary outcome parameter). } \\
\text { Compared to tioitropium, tiotropium/ } \\
\text { Salm/FP improved FEV }(p=0.049) \\
\text { and quality of life }(p=0.01) \text {. }\end{array}$ & 1 year \\
\hline
\end{tabular}

* on treatment of COPD using ICS or ICS/LABA and with a study duration of $\geq 12$ months

$\mathrm{Bec}$, beclomethasone; Bud, budesonide; COPD, chronic obstructive pulmonary disease; FEV ${ }_{1}$, forced expiratory volume in 1 second in pulmonary function testing; Form, formoterol; FP, fluticasone propionate; ICS, inhaled corticosteroids; INSPIRE, Investigating New Standards for Prophylaxis in Reduction of Exacerbations; ISOLDE, Inhaled Steroids in Obstructive Lung Disease in Europe; LABA, long-acting $\beta_{2}$-agonists; pack-years, average cigarettes consumption (1 pack-year = 1 pack of 20 cigarettes smoked every day for 1 year); Salm, salmeterol; SGRQ, St. George Respiratory Questionnaire; TORCH, Towards a Revolution in COPD Health; TRISTAN, Trial of Inhaled Steroids and Long-Acting $\beta_{2}$-Agonists 